\title{
Corrigendum
}

\section{Book Review: JAMES GILHAM. Loyal Enemies: British Converts to Islam, 1850-1950 - CORRIGENDUM}

\section{Clinton Bennett}

doi:10.1017/jbr.2015.33, published in Journal of British Studies 54:2, April 2015.

In the original publication of Clinton Bennett's book review for Loyal Enemies: British Converts to Islam, 1850-1950, ${ }^{1}$ the author of Loyal Enemies was incorrectly cited as James Gilham. The author's name is Jamie Gilham. Both the author and the JBS book review editors regret this error. 